Discussion Paper No. 06-067

\title{
Taxation and Capital Structure Choice - Evidence from a Panel of German Multinationals
}

Thiess Buettner, Michael Overesch, Ulrich Schreiber and Georg Wamser

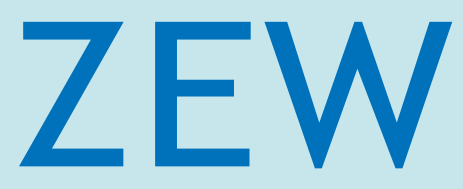

Zentrum für Europäische Wirtschaftsforschung $\mathrm{GmbH}$

Centre for European

Economic Research 
Discussion Paper No. 06-067

\title{
Taxation and Capital Structure Choice - Evidence from a Panel of German Multinationals
}

\author{
Thiess Buettner, Michael Overesch, \\ Ulrich Schreiber and Georg Wamser
}

Download this ZEW Discussion Paper from our ftp server:

ftp://ftp.zew.de/pub/zew-docs/dp/dp06067.pdf

Die Discussion Papers dienen einer möglichst schnellen Verbreitung von neueren Forschungsarbeiten des ZEW. Die Beiträge liegen in alleiniger Verantwortung der Autoren und stellen nicht notwendigerweise die Meinung des ZEW dar.

Discussion Papers are intended to make results of ZEW research promptly available to other economists in order to encourage discussion and suggestions for revisions. The authors are solely responsible for the contents which do not necessarily represent the opinion of the ZEW. 


\section{Non-Technical Summary}

While all companies will respond to taxation and capital market conditions with their financing and investment decisions, multinational companies seem to have enhanced opportunities. In particular, they may be able to structure their internal finances in order to save taxes. This channel of response to taxation has not only important implications for the revenue consequences of tax policy, but may also shape the response of multinationals' investment decisions to specific tax policy decisions.

This paper investigates the effects of company taxation and capital market conditions on the financial structure of multinationals' foreign affiliates. A theoretical model considers the financing and investment decisions of a multinational corporation and derives empirical implications. More specifically, we model a company, active in two countries, which has the opportunity to use equity as well as external and internal debt. The theoretical model shows that the effect of local taxes on leverage is positive for both channels of finance.

The empirical implications are then investigated using a micro-level panel database (MiDi) provided by Deutsche Bundesbank of affiliates of German multinationals in 26 countries in the period from 1996 until 2003. The panel data structure and the possibility to identify all foreign affiliates belonging to the considered multinational allows us to control for the heterogeneity across companies. A further advantage of the data is that under German tax law repatriated foreign profits are almost completely exempt from corporation taxes such that the taxes at the location of the affiliate are decisive for the financing and investment decisions. The empirical analysis of the capital structure choice of multinationals confirms that the local tax rate exerts important effects on affiliate's use of external as well as internal debt. Moreover, while adverse local credit market conditions are confirmed to reduce external borrowing, internal debt is increasing. This supports the view that the two channels of debt finance are substitutes. Comparing our results with results in the US case (Desai, Foley and Hines, 2004) we find similar effects of taxation and credit market 
conditions on capital structure. This suggests that the international tax regime with regard to exemption vs. tax credit method has little impact on the tax sensitivity of finances. 


\title{
Taxation and Capital Structure Choice - Evidence from a Panel of German Multinationals
}

\author{
Thiess Buettner \\ (Ifo Institute and Munich University $(\mathrm{LMU}))^{\dagger}$ \\ Michael Overesch \\ (ZEW) \\ Ulrich Schreiber \\ (Mannheim University and ZEW) \\ Georg Wamser \\ (Ifo Institute) \\ July 2006
}

\begin{abstract}
This paper analyzes the impact of taxes and lending conditions on the financial structure of multinationals' foreign affiliates. The empirical analysis employs a large panel of affiliates of German multinationals in 26 countries in the period from 1996 until 2003. In accordance with the theoretical predictions, the effect of local taxes on leverage is positive for both types of debt. Moreover, while adverse local credit market conditions are found to reduce external borrowing, internal debt is increasing, supporting the view that the two channels of debt finance are substitutes.
\end{abstract}

Keywords: Corporate Income Tax; Multinationals; Capital Structure; Firm-Level Data JEL Classification: H25, H26, G32

\footnotetext{
$\dagger$ Address: Ifo Institute for Economic Research Poschingerstr. 5

Phone: $\quad+498992241319$

D-81679 Munich

Fax: $\quad+498992242319$

Germany

E-mail: buettner@ifo.de
} 


\section{Introduction}

Multinational corporations use not only external capital but also intercompany loans in order to optimize their capital structure. This might contribute to a lower sensitivity of investment decisions to differences in taxation across countries, and, in addition, aggravates the adverse revenue consequences of tax planning for tax policy. While the impact of taxes on finances is well established in the literature on corporation taxes (see Auerbach, 2002, and Graham, 2003, for a survey), the multinationals' choice of the capital structure has only recently been addressed in the empirical literature. For Canadianand US-controlled firms Jog and Tang (2001) found a significant impact of tax rate differentials between Canada and the US. For a sample of US controlled affiliates Desai, Foley, and Hines (2004) show that especially internal borrowing of US corporations is sensitive to taxation. It is, however, not obvious whether these results can be generalized to other countries where multinationals are not subject to a tax credit system. The current paper considers the impact of taxes on the capital structure of German corporations for which, as is typical for EU countries, repatriated foreign profits are basically exempt from corporation taxes.

\section{Theoretical Background}

Following Modigliani and Miller (1958, 1963), corporations would generally favor debt, since the tax shield from deductible interest expenses increases the company value. In order to explain why corporations nevertheless use equity, the literature uses alternative theories (see Myers, 2001, and Auerbach, 2002). Generally, these theories stress the trade-off between the gains from the tax shield through interest deductions and the agency cost of debt, reflecting the inability to solve potential conflict between equity and debt claimants by means of contracts (Jensen and Meckling, 1976, and Myers, 1977). 
To derive the optimal capital structure, consider the profit function for a multinational

$$
\begin{aligned}
\pi & =f\left(k_{1}\right)\left(1-t_{1}\right)+f\left(k_{2}\right)\left(1-t_{2}\right) \\
& -\left[i_{1} \lambda_{1} k_{1}+i_{2} \mu_{1} k_{1}\right]\left(1-t_{1}\right) \\
& -\left[i_{2} \lambda_{2} k_{2}+i_{1} \mu_{2} k_{2}\right]\left(1-t_{2}\right) \\
& -r\left[k_{1}\left(1-\lambda_{1}-\mu_{1}\right)+k_{2}\left(1-\lambda_{2}-\mu_{2}\right)\right] \\
& -\left[c_{1}\left(\lambda_{1}, \mu_{1}\right) k_{1}+c_{2}\left(\lambda_{2}, \mu_{2}\right) k_{2}\right],
\end{aligned}
$$

where $f\left(k_{i}\right)$ denotes the output at location $i$ where $k_{i}$ units of capital are employed. $t_{i}$ is the local tax rate on capital income. The second and third lines capture the cost of debt, where $\mu_{i}, \lambda_{i}$ denote the share of capital financed with internal and external debt, respectively. Internal debt is remunerated at the other location's interest rate. ${ }^{1}$ While the fourth line contains the opportunity cost of equity, the last line captures the agency cost of debt, which is not only increasing in both external and internal debt but also convex $\quad c_{j, \mu \mu} \equiv \frac{\partial^{2} c_{j}}{\partial \mu_{j}^{2}}>0, \quad c_{j, \lambda \lambda} \equiv \frac{\partial^{2} c_{j}}{\partial \lambda_{j}^{2}}>0$. If the cross-partial derivative $c_{j, \lambda \mu} \equiv \frac{\partial^{2} c_{j}}{\partial \lambda_{j} \partial \mu_{j}}$ is positive, the two types of finance are substitutes, since the marginal agency cost for each type of debt would increase if the other type of debt is used more heavily. We further impose some regularity conditions $\quad c_{j, \mu \mu}>\left|c_{j, \mu_{j} \lambda_{j}}\right|, \quad$ and $c_{j, \lambda \lambda}>\left|c_{j, \lambda_{j} \mu_{j}}\right|$ such that cross-effects are always dominated by the own effects.

The profit function assumes that the lending part of the multinational incurs debt in order to finance the loan, implying that the required rate of return on equity is higher than the net-of-tax cost of debt. This assumption is likely to be met if the lending part is located in a high-tax country, such that there is little incentive to transform foreign into domestic profits. ${ }^{2}$ We retain this assumption, since the empirical analysis is concerned with the case of German multinationals, where the parent company is indeed located in a high tax country.

\footnotetext{
${ }^{1}$ The company might have an incentive to set the interest rates above the market value, but we assume that the arm's length principle is effective.

${ }^{2}$ The alternative case is discussed by Mintz and Smart (2005).
} 
Given the profit function the optimum share of external debt incurred by affiliate 2 obeys

$$
r-\left(1-t_{2}\right) i_{2}=c_{2, \lambda}\left(\lambda_{2}, \mu_{2}\right)
$$

The convexity of $c_{2}$ implies that if $r>\left(1-t_{2}\right) i_{2}, \lambda_{2}$ is positive. Thus, if the after-tax return to capital is below the required rate of return on equity, there will be some external borrowing. The optimum share of internal funds used at location 2 is determined by

$$
r-\left(1-t_{2}\right) i_{1}=c_{2, \mu}\left(\lambda_{2}, \mu_{2}\right)
$$

If the after-tax return to capital for intercompany debt is below the required rate of return on equity $r>\left(1-t_{2}\right) i_{1}$, a part of the capital invested at location 2 is financed with internal debt.

\section{Data and Specification}

The first-order conditions give rise to two basic testable relationships for the finances of foreign affiliates of German multinationals. The comparative static properties, derived in an appendix to this paper, suggest that external capital used at location $j$ should decline in the pre-tax rate of interest but increase in the local tax rate. With regard to intercompany loans our analysis suggests that the amount of intercompany loans used at a location is an increasing function of the local tax rate as it reduces the net-of-tax rate of interest. Via its impact on external borrowing, however, also the local interest rate will matter. Given these considerations, the same estimation equation can be used for either type of leverage of an affiliate in country $j$ held by a German multinational $k$ in period $t$

$$
Y_{j, k, t}=a_{0}+a_{1} x_{j, k, t}+a_{2} t_{j, t}+a_{3} \log i_{j, t}+a_{k}+a_{t}+\epsilon_{j, t},
$$

where $a_{t}$ is a time-specific and $a_{k}$ group-specific effect for all affiliates held by company $k$. Note that the former also captures the interest rate at the parent location as 
we consider only German multinationals. The company-specific effect encompasses the company-specific opportunity cost of capital $r$ which might also include elements of personal taxation at the level of the shareholder. $x_{j, k, t}$ captures further characteristics of the subsidiary which affect the use of debt or the access to credit. As the lending rate is difficult to measure we separate out its impact from that of taxes, captured by the tax rate as an approximation to the log of unity minus tax rate.

The empirical analysis uses a Bundesbank database providing annual firm-level panel data for the period 1996 to 2003. The collection of the data is prescribed by German law, which determines reporting mandates for international transactions (Lipponer, 2006). Since the model assumes a two-tier company structure, we focus on majority owned subsidiaries and exclude indirectly held investment. Furthermore, as the underlying model deals with a case where production takes place at each location, holdings and financial service providers as well as observations with non-positive capital and turnover are excluded as well.

In order to capture the tax incentive, the analysis employs the statutory tax rate on corporate income modified by applicable restrictions on interest deductions. Thus, the statutory tax rate represents the tax savings from deducting one unit of interest. Since the effective tax reduction from using debt is zero if there is a loss carry-forward (MacKieMason, 1990) a corresponding dummy variable is included. In the lack of information about firm-specific interest expenses, we employ the lending rates for credit to the private sector taken from the IMF, augmented, where possible, with ECB data. In order to control for further variation in the lending conditions we employ turnover as an indicator of size and cash-flow of the affiliate both of which will generally be positively associated with the lending conditions. As agency cost may also vary across industries, we control for further heterogeneity by including dummies for 71 industries at the level of the affiliate. Table 1 reports descriptive statistics. 
Table 1: Descriptive Statistics

\begin{tabular}{l|rrrr}
\hline \hline & Mean & Std. Dev. & Min. & Max. \\
\hline Capital $(€ 1,000)$ & 31,258 & 175,776 & 112 & $15,200,000$ \\
Turnover (€1,000) & 52,486 & 370,006 & 1,000 & $51,900,000$ \\
External leverage & .364 & .250 & 0 & 1 \\
Internal leverage & .248 & .250 & 0 & 1 \\
Statutory tax rate & .346 & .068 & .100 & .532 \\
Loss carry-forward & .292 & .455 & 0 & 1 \\
Lending rate & .075 & .044 & .027 & .364 \\
\hline
\end{tabular}

40,300 observations covering subsidiaries in 26 host countries in the eight years from 1996 - 2003. Tax rate and lending rate vary only by country-year cells

\section{Results}

Columns (1)-(3) of Table 2 report estimation results for the ratio of external debt to the affiliate's total stock of capital. The results confirm a positive impact of taxes and an adverse effect of local lending conditions on the leverage. The presence of a loss carryforward exerts a weak negative impact, indicating that a loss carry-forward either directly reduces the gain from tax savings by debt finance, or, alternatively, that uncertainties hamper access to credit. The positive sign of turnover in column (2) is in accordance with the view that a larger size or cash-flow improves the access to external capital. Column (3) shows that the results are robust if also industry dummies control for further heterogeneity among affiliates. Columns (4)-(6) report results for internal debt. Again, we find a significant positive effect of the statutory tax rate. After inclusion of controls for industries and turnover, the coefficient is only slightly smaller than in the case of external debt. The effect of the lending rate, however, differs, showing a positive effect on the share of internal debt. This conforms with the view that external and internal debt are substitutes. A substitutive relationship is further in accordance with the results for the turnover, which exerts opposite effects on external and internal debt.

While the empirical results represent average effects, some affiliates report zero levels of external and/or internal capital, where specific conditions may impede an interior 
solution. The results shown in the appendix are not much different.

The impact of local lending conditions is in accordance with Desai et al., who employ indicators of the local credit market including the rate of inflation, measures of country risk, creditor rights, and the size of the credit market. As shown in the appendix, the empirical variation in the lending rate used in our analysis can be well predicted by their measures. Consequently, alternative estimations using the predicted lending rate or instrumental variable approaches obtained rather similar results.

Table 2: Results

\begin{tabular}{|c|c|c|c|c|c|c|}
\hline \multirow[t]{2}{*}{ Dependent variable } & \multicolumn{3}{|c|}{ Share of External Debt } & \multicolumn{3}{|c|}{ Share of Internal Debt } \\
\hline & $(1)$ & $(2)$ & $(3)$ & $(4)$ & $(5)$ & $(6)$ \\
\hline Statutory tax rate & $\begin{array}{l}.240 \text { * } \\
(.046)\end{array}$ & $\begin{array}{l}.177^{\star} \\
(.050)\end{array}$ & $\begin{array}{l}.187^{\star} \\
(.050)\end{array}$ & $\begin{array}{l}.1355^{\star} \\
(.032)\end{array}$ & $\begin{array}{l}.1922^{\star} \\
(.033)\end{array}$ & $\begin{array}{l}.153^{\star} \\
(.033)\end{array}$ \\
\hline (log)Lending rate & $\begin{array}{l}-.042 \text { * } \\
(.006)\end{array}$ & $\begin{array}{l}-.035 * \\
(.007)\end{array}$ & $\begin{array}{l}-.037^{\star} \\
(.007)\end{array}$ & $\begin{array}{l}.039{ }^{\star} \\
(.005)\end{array}$ & $\begin{array}{l}.032 \\
(.005)\end{array}$ & $\begin{array}{l}.0433^{\star} \\
(.005)\end{array}$ \\
\hline $\begin{array}{l}\text { Loss carry-forward } \\
(\log ) \text { Turnover }\end{array}$ & $\begin{array}{l}-.007 \text { * } \\
(.003)\end{array}$ & $\begin{array}{l}-.003 \\
(.003) \\
.028 \\
(.002)\end{array}$ & $\begin{array}{l}-.003 \\
(.003) \\
.027 \star \\
(.002)\end{array}$ & $\begin{array}{l}.059 \text { * } \\
(.004)\end{array}$ & $\begin{array}{l}.055^{\star} \\
(.004) \\
-.025^{\star} \\
(.002)\end{array}$ & $\begin{array}{l}.059{ }^{\star} \\
(.004) \\
-.016{ }^{\star} \\
(.002)\end{array}$ \\
\hline $\begin{array}{l}\text { Industry effects } \\
R^{2}\end{array}$ & $\begin{array}{l}\text { no } \\
.029\end{array}$ & $\begin{array}{l}\text { no } \\
.044\end{array}$ & $\begin{array}{l}\text { yes } \\
.052\end{array}$ & $\begin{array}{l}\text { no } \\
.022\end{array}$ & $\begin{array}{c}\text { no } \\
.032\end{array}$ & $\begin{array}{l}\text { yes } \\
.068\end{array}$ \\
\hline
\end{tabular}

Company and time fixed effects included. Standard errors are robust against random firm-specific and country effects using the usual Huber-White sandwich formula. An asterisk denotes significance at 5\% level. 40,300 observations, 4,115 firms.

With regard to the magnitude of the estimated effects, the results suggest that a 10 percentage point increase in the statutory tax rate on corporate earnings is associated approximately with a 1.9 percentage point increase in the external debt ratio (column 3) and a 1.5 percentage point increase in the internal debt ratio (column 6), taken together the leverage increases by 3.4 percentage points. This is partly consistent with Mintz and Weichenrieder (2005), who find that German multinationals respond almost exclusively with internal debt. However, our results do support effects on external debt as well.

Comparing our results with Desai, Foley and Hines (2004) we find that the elasticity of external borrowing implied by the point estimate is rather similar. Evaluated at mean 
values of taxes and leverage, the elasticity of external borrowing is 0.18 in the German case compared with 0.19 in the US case. The elasticity of internal borrowing in the German case is, however, only 0.21 as compared to 0.35 in the US case.

\section{Conclusions}

The empirical analysis of the capital structure choice of multinationals confirms that the local tax burden exerts important effects on the affiliate's leverage. This refers not only to external debt; our findings indicate that a higher local tax rate is also associated with an increase in internal debt. This shows that multinationals have access to an additional instrument which can be used to exploit the tax savings opportunities of debt finance.

The failure to find a higher tax sensitivity in the German as compared to the US case indicates that the international tax regime with regard to tax exemption vs. tax credit has little impact on the tax sensitivity of finances. This suggests that the foreign tax credit may actually be alleviated by deferred repatriation of profits (e.g., Hines and Rice, 1994, Altshuler and Grubert, 2003, Grubert, 2003) or other forms of tax planning.

A final remark is in order on the potential role of constraints such as thin-capitalization rules. Given the existence of such rules, the tax sensitivity of the capital structure might be underestimated to some extent. The analysis of the consequences of those constraints is, however, left for future research. 


\section{Appendix}

\section{Comparative Static Effects}

We can derive the comparative static properties by differentiating the system of the two first-order conditions which we obtained from our profit function.

$$
\left[\begin{array}{c}
i_{2} d t_{2}-\left(1-t_{2}\right) d i_{2} \\
i_{1} d t_{2}-\left(1-t_{2}\right) d i_{1}
\end{array}\right]=\left[\begin{array}{ll}
c_{2, \lambda \lambda} & c_{2, \lambda \mu} \\
c_{2, \lambda \mu} & c_{2, \mu \mu}
\end{array}\right]\left[\begin{array}{l}
d \lambda_{2} \\
d \mu_{2}
\end{array}\right]
$$

Solving for the respective channel of finance we can state the corresponding comparative static effects. Let us consider first the effects of the interest rate on external debt

$$
\frac{d \lambda_{2}}{d i_{2}}=(1 /|H|)\left(-\left(1-t_{2}\right) c_{2, \mu \mu}\right)<0
$$

where the determinant of the Hessian $|H|$ is positive given the regularity assumptions about the cost function. ${ }^{3}$ Thus, the expression is unambiguously negative, indicating that an increase in the local interest rate causes a reduction in the external leverage.

With regard to internal debt we obtain

$$
\frac{d \mu_{2}}{d i_{2}}=(1 /|H|)\left(+\left(1-t_{2}\right) c_{2, \lambda \mu}\right) \gtrless 0 .
$$

Assuming that the two types of debt act as substitutes $\left(c_{2, \lambda \mu}>0\right)$ the expression is positive, indicating that an increase in the local interest rate causes an increase in intercompany debt. Making use, once more, of the imposed regularity conditions we note that the direct impact on external borrowing (4) always dominates and total leverage declines.

Furthermore, let us consider the effects of the tax rate

$$
\frac{d \lambda_{2}}{d t_{2}}=(1 /|H|)\left(i_{2} c_{2, \mu \mu}-i_{1} c_{2, \lambda \mu}\right) \gtrless 0 .
$$

Given the two types of debt act as substitutes $\left(c_{2, \lambda \mu}>0\right)$, the sign is ambiguous. But if the interest rate at the parent location is not much higher than the interest rate at the affiliate, the derivative will be positive: higher taxation leads to a higher leverage. Similarly, for the intercompany loans:

$$
\frac{d \mu_{2}}{d t_{2}}=(1 /|H|)\left(i_{1} c_{2, \lambda \lambda}-i_{2} c_{2, \lambda \mu}\right) \gtrless 0 .
$$

If the interest rates differ not much, higher taxation also leads to a higher leverage related to intercompany loans.

${ }^{3} \quad c_{j, \mu \mu}>\left|c_{j, \mu_{j} \lambda_{j}}\right|$, and $c_{j, \lambda \lambda}>\left|c_{j, \lambda_{j} \mu_{j}}\right|$ 
Table 3: Descriptive Statistics for Outbound FDI

\begin{tabular}{|c|c|c|c|c|c|c|}
\hline \multirow[b]{2}{*}{ Destination Country } & \multicolumn{2}{|c|}{ Observations } & \multirow{2}{*}{$\begin{array}{c}\text { Capital } \\
(€ 1,000) \\
\text { Mean }\end{array}$} & \multirow{2}{*}{$\begin{array}{c}\text { Share of } \\
\text { Debt } \\
\text { Mean }\end{array}$} & \multirow{2}{*}{$\begin{array}{c}\text { Share of } \\
\text { Ext. Debt } \\
\text { Mean }\end{array}$} & \multirow{2}{*}{$\begin{array}{c}\text { Share of } \\
\text { Int. Debt } \\
\text { Mean }\end{array}$} \\
\hline & Number & Percent & & & & \\
\hline Australia & 852 & 2.11 & 17,715 & .619 & .303 & .316 \\
\hline Austria & 2,601 & 6.45 & 25,318 & .605 & .380 & .225 \\
\hline Belgium & 1,666 & 4.13 & 43,044 & .634 & .381 & .253 \\
\hline Canada & 679 & 1.68 & 31,141 & .541 & .316 & .225 \\
\hline Czech Republic & 2,180 & 5.41 & 25,151 & .623 & .360 & .264 \\
\hline Denmark & 765 & 1.90 & 18,844 & .656 & .404 & .253 \\
\hline Finland & 304 & 0.75 & 19,589 & .566 & .325 & .240 \\
\hline France & 4,861 & 12.06 & 27,890 & .646 & .405 & .241 \\
\hline Great Britain & 3,312 & 8.22 & 29.949 & .560 & .350 & .246 \\
\hline Greece & 404 & 1.00 & 22,245 & .651 & .373 & .278 \\
\hline Hungary & 1,368 & 3.39 & 36,191 & .564 & .335 & .229 \\
\hline Ireland & 331 & 0.82 & 19,575 & .502 & .279 & .224 \\
\hline Italy & 3,305 & 8.20 & 28,951 & .720 & .439 & .282 \\
\hline Japan & 954 & 2.37 & 54.095 & .672 & .460 & .211 \\
\hline Luxembourg & 58 & 0.14 & 17,254 & .702 & .496 & .206 \\
\hline Mexico & 562 & 1.39 & 62,787 & .512 & .245 & .267 \\
\hline Netherlands & 2,133 & 5.29 & 28,528 & .576 & .336 & .240 \\
\hline New Zealand & 116 & 0.29 & 11,101 & .536 & .269 & .267 \\
\hline Norway & 327 & 0.81 & 26,060 & .605 & .345 & .260 \\
\hline Poland & 2,533 & 6.29 & 19,448 & .610 & .341 & .269 \\
\hline Portugal & 317 & 0.79 & 24,813 & .562 & .344 & .218 \\
\hline Slovakia & 448 & 1.11 & 28,476 & .566 & .328 & .238 \\
\hline Spain & 2,739 & 6.80 & 33,263 & .607 & .379 & .227 \\
\hline Sweden & 934 & 2.32 & 20,638 & .614 & .339 & .274 \\
\hline Switzerland & 2,610 & 6.48 & 18.674 & .549 & .367 & .182 \\
\hline USA & 3,941 & 9.78 & 57,781 & .583 & .300 & .283 \\
\hline Total & 40,300 & 100.00 & 31,258 & .612 & .364 & .248 \\
\hline
\end{tabular}

Descriptive statistics for the estimation sample covering German outbound FDI in the period from 1996 until 2003. The list of host countries includes 26 countries, 14 of these countries are EU members in the period analyzed. 
Table 4: Results for Non-Zero Observations

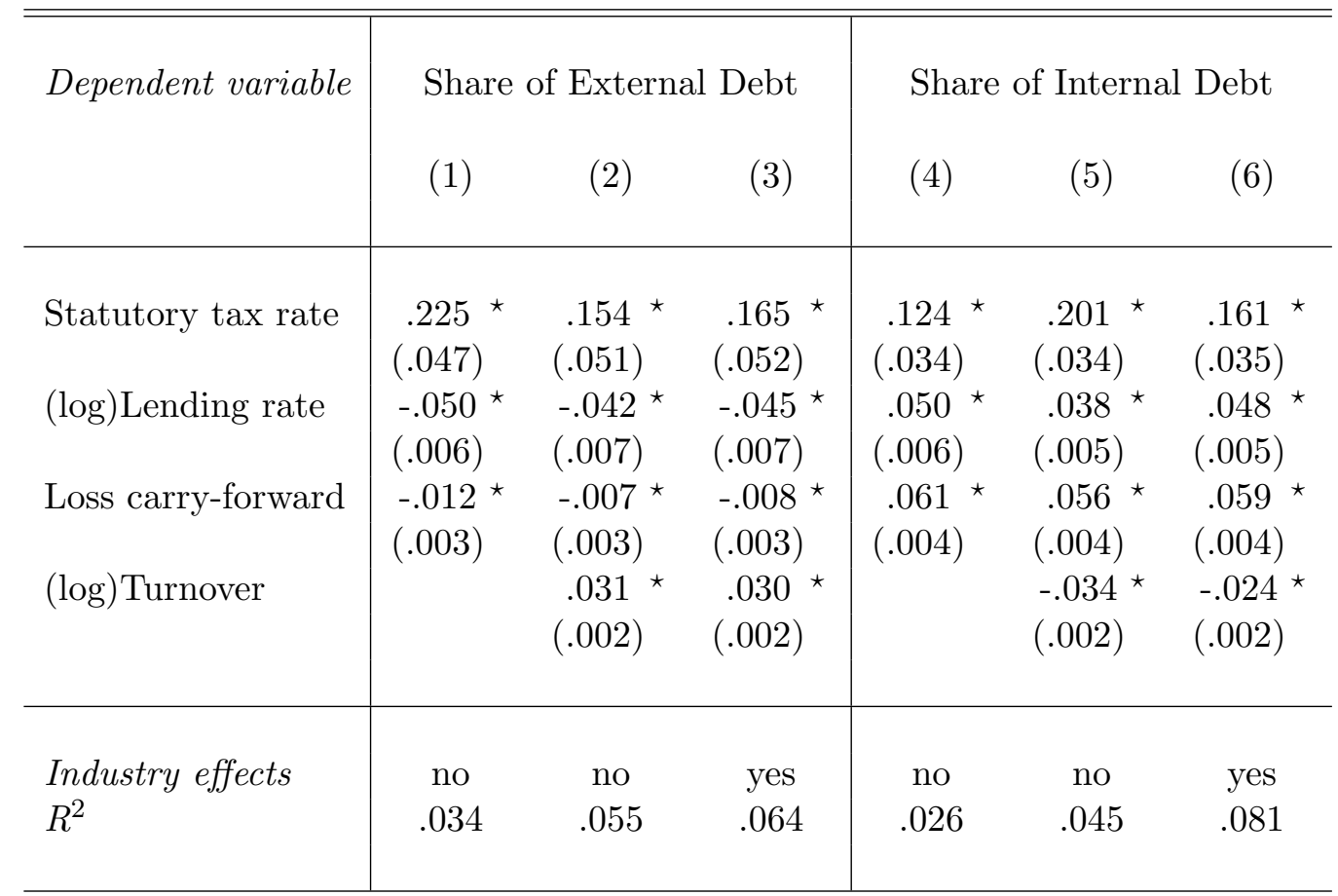

Empirical results for observations with non-zero debt only. The sample size is reduced slightly. Company level and time fixed effects included. Standard errors are robust against random firm-specific and country effects using the usual Huber-White sandwich formula. An asterisk denotes significance at 5\% level. 35,469 observations, 3,761 firms. 
Table 5: Determinants of the Lending Rate

\begin{tabular}{l|cccc}
\hline \hline & $(1)$ & $(2)$ & $(3)$ & $(4)$ \\
& & & & \\
\hline \multirow{2}{*}{ Inflation } & $1.03 \star$ & $.691 \star$ & $.692 \star$ & $.667 \star$ \\
& $(.058)$ & $(.068)$ & $(.068)$ & $(.071)$ \\
Country risk & & $2.47 \star$ & $2.25 \star$ & 2.37 \\
& & $(.476)$ & $(.502)$ & $(.526)$ \\
Private credit & & & -.004 & -.000 \\
& & & $(.003)$ & $(.004)$ \\
Creditor rights & & & & $-.195 \star$ \\
& & & & $(.098)$ \\
& & & & \\
\hline \multirow{2}{*}{$\mathrm{R}^{2}$} & .808 & .810 & .816 \\
& & & & \\
\hline
\end{tabular}

Determinants of the lending rate for the panel of 26 host countries from 1996 to 2003. Inflation is taken from World Economic Outlook Database. Country risk is an index provided by the German investment credit insurance agency which ranks from 1 (low risk) to 7 (high risk). Private credit represents the ratio of domestic credit to the private sector to GDP in \% taken from World Development Indicators as provided by the World Bank. The Creditor rights index is also taken from the World Bank. It ranges from 0 to 10, with higher scores indicating that the risk to the creditor is lower. Standard errors are robust to heteroscedasticity. An asterisk denotes significance at $5 \%$ level. Time dummies are included. 184 observations covering 26 countries over 8 years. 


\section{Datasources and Definitions}

Data for foreign affiliates of German multinationals are taken from the MiDi database of the German Bundesbank. The dataset is augmented with time varying information for 26 countries, 14 of these countries are EU members in the period analyzed. This list of countries includes: Australia, Austria, Belgium, Canada, Czech Republic, Denmark, Finland, France, Great Britain, Greece, Hungary, Ireland, Italy, Japan, Luxembourg, Mexico, Netherlands, New Zealand, Norway, Poland, Portugal, Slovakia, Spain, Sweden, Switzerland, and USA.

Corporation tax data are taken from the IBFD, Ernst\&Young, PwC, and KPMG. The tax rate employed contains statutory profit taxes modified by applicable general restrictions on interest deductions. The source of lending rates is the IMF, see above.

\section{References}

Altshuler, R. and H. Grubert (2003), Repatriation taxes, repatriation strategies and multinational financial policy, Journal of Public Economics 87, 73 - 107.

Auerbach, A.J. (2002), Taxation and corporate financial policy, in: Auerbach A.J. and M. Feldstein (ed.), Handbook of Public Economics, Vol. 3, Amsterdam, 1251-1292.

Desai, M.A., C.F. Foley and J.R. Hines (2004), A multinational perspective on capital structure choice and internal capital markets, The Journal of Finance 59, 24512487.

Gordon, R.H. and Y. Lee (2001), Do taxes affect corporate debt policy? Evidence from U.S. corporate tax return data, Journal of Public Economics 82, 195 - 224.

Graham, J.R. (2003), Taxes and corporate finance: a review, The Review of Financial Studies 16, 1075 - 1129.

Grubert, H. (2003), The tax burden on cross-border investment: company strategies and country responses, CESifo Working paper 964.

Hines, J.R. and E.M. Rice (1994), Fiscal paradise: foreign tax havens and american business, Quarterly Journal of Economics 109, 149 - 182.

Jensen, M. and W.H. Meckling (1976), Theory of the firm: managerial behavior, agency costs and ownership structure, Journal of Financial Economics 42, 159-185. 
Jog, V. and J. Tang (2001), Tax reforms, debt shifting and tax revenues: multinational corporations in Canada, International Tax and Public Finance 8, 5-26.

Lipponer, A. (2006), Microdatabase Direct Investment - MiDi. A Brief Guide. Bundesbank Working Paper, Frankfurt.

MacKie-Mason, J. (1990), Do taxes affect corporate financing decisions? The Journal of Finance 45, 1471-1493.

Mintz, J. and M. Smart (2004), Income Shifting, investment, and tax competition: theory and evidence from provincial taxation in Canada, Journal of Public Economics $88,1149-1168$.

Mintz, J. and A.J. Weichenrieder (2005), Taxation and the financial structure of German outbound FDI, CESifo Working Paper 1612, Munich.

Modigliani, F. and M. Miller (1958), The cost of capital, corporation finance, and the theory of investment, American Economic Review 48, 261-297.

Modigliani, F. and M. Miller (1963), Corporate income taxes and the cost of capital: a correction, American Economic Review 53, 443-453.

Myers, S. (1977), Determinants of corporate borrowing, Journal of Financial Economics $5,147-175$.

Myers, S. (2001), Capital Structures, Journal of Economic Perspectives 15, 81-102. 